\title{
PENGARUH KARTU JAKARTA PINTAR (KJP) TERHADAP MOTIVASI BELAJAR SISWA KELAS XII DI SMK DHARMA PUTRA 1 JAKARTA
}

\author{
Nia Mala Sari ${ }^{1}$, Chientya Annisa Rahman Putrie ${ }^{2(*)}$, Nurhayati ${ }^{3}$ \\ STKIP Panca Sakti, Indonesia \\ niamalasari96@gmail.com ${ }^{1}$,Chientya2725@gmail.com ${ }^{2}$,nurrybachrudin19@gmail.com ${ }^{3}$
}

Received: 07 Juli 2020

Revised: 29 Juli 2020

Accepted: 21 September 2020

\begin{abstract}
Penelitian ini bertujuan untuk mengetahui apakah terdapat pengaruh kartu jakarta pintar terhadap motivasi belajar siswa di SMK Dharma Putra 1 Jakarta. Jenis penelitian yang dilakukan adalah kuantitatif dengan metode survey. Teknik pengumpulan data yang dilakukan adalah melalui observasi, wawancara dan kuesioner. Populasi dalam penelitian ini adalah siswa/i SMK Dharma Putra 1 Jakarta sebanyak 109, Sampel dalam penelitian ini ialah siswa penerima bantuan Kartu Jakarta Pintar (KJP) dari kelas XII yang berjumlah sebanyak 86 orang siswa. Teknik pengambilan sampel menggunakan simple random sampling. Hipotesis yang diajukan "Terdapat Pengaruh Kartu Jakarta Pintar (KJP) terhadap Motivasi Belajar Siswa di SMK Dharma Putra 1 Jakarta". Hasil Penelitian menunjukan adanya pengaruh kartu jakarta pintar terhadap motivasi belajar siswa di SMK Dharma Putra 1 Jakarta. Penelitian ini menunjukan bahwa dengan Kartu Jakarta Pintar (KJP) dapat memenuhi dasar pendidikan dan meningkatkan motivasi belajar siswa. dengan KJP ini untuk siswa agar meningkatkan prestasi belajar, kepada pihak sekolah agar membuat program peningkatan motivasi belajar dan untuk Provinsi DKI Jakarta agar lebih dapat memonitoring dan mengevaluasi sekolah-sekolah yang mendapatkan program bantuan ini.
\end{abstract}

Keywords: Program; Kartu Jakarta Pintar; KJP; Motivasi Belajar

(*) Corresponding Author:

Putrie, Chientya2725@gmail.com,082169000509

How to Cite: Sari, M. N., Putrie, C. A. R., \& Nurhayati. (2020). Pengaruh Kartu Jakarta Pintar (KJP) Terhadap Motivasi Belajar Siswa Kelas XII Di SMK Dharma Putra 1 Jakarta. Research and Development Journal of Education, 1(1), 01-11.

\section{INTRODUCTION}

Presiden Republik Indonesia melalui Peraturan Gubernur No. 4 Tahun 2018. Mencapaikan tujuan dalam untuk meningkatkan efektifitas dan efisiensi program untuk mencapai tujuan. Upaya pemerintah untuk memberikan kesempatan seluas-luasnya kepada masyarakat agar memperoleh layanan pendidikan yaitu salah satunya melalui program Kartu Jakarta Pintar (KJP). Program tersebut diharapkan dapat membangun generasi yang unggul dan masyarakat generasi muda mendapatkan pendidikan.

Pemerintah Provinsi DKI Jakarta membuat program Kartu Jakarta Pintar (KJP) yaitu program strategis untuk memberikan akses bagi warga DKI Jakarta dari kalangan masyarakat tidak mampu untuk mengenyam pendidikan minimal sampai dengan tamat SMA/SMK dengan dibiayai penuh dari dana APBD Provinsi DKI Jakarta.

Pendidikan adalah pengetahuan, keterampilan, dan serta Pembelajaran kebiasaan sekelompok orang yang diturunkan dari satu generasi ke generasi berikutnya melalui pengajaran, pelatihan, atau penelitian. Pendidikan sering terjadi di bawah bimbingan orang lain, tetapi juga memungkinkan secara otodidak. Sebuah hak atas pendidikan telah 
diakui oleh beberapa pemerintah. Banyaknya anak yang tidak dapat mengikuti sekolah selama 12 tahun.

Kartu Jakarta Pintar merupakan strategi pemerintah untuk memberikan akses kepada warga DKI Jakarta yang dikategorikan masyarakat tidak mampu dalam pembiayaan pendidikan samapai dengan SMA/SMK sederajat yang dibiayai penuh dari APBD Provinsi DKI Jakarta. Upaya tersebut terus berlanjut sehingga dicanangkannya Wajib Belajar 12 tahun DKI Jakarta pada tahun 2012. Sebagai Ibu Kota negara tentunya menjadikan DKI Jakarta menjadi tujuan utama bagi arus urbanisasi seperti apa yang telah disampaikan sebelumnya. Tentunya dengan semakin meningkatnya angka urbanisasi disetiap tahunnya menjadikan karakteristik masyarakat DKI Jakarta menjadi sangat heterogen. Dengan latarbelakang seperti itu tentunya persoalan-persoalan terkait dengan pendidikan menjadi lebih beragam.

Salah satu faktor rendahnya kualitas pendidikan di Indonesia adalah masalah kemiskinan. Masyarakat miskin berpandangan bahwa masalah perut lebih kruisal dibandingkan dengan pendidikan, oleh karena itu banyak penduduk miskin di seluruh Indonesia yang tidak menamatkan pendidikannya sampai Wajib Belajar 12 tahun seperti yang direncanakan oleh pemerintah. Mahalnya biaya pendidikan membuat masyarakat miskin berpikir dua kali dalam memberikan pendidikan bagi anggota keluarga mereka.

Kasus kemiskinan dipengaruhi oleh tingkat pendidikan yang masih rendah, rendahnya derajat kesehatan, lapangan kerja yang terbatas dan kurang memadai, ketidakpedulian terhadap keadaan sosial di sekitar, malas bekerja, keterbatasan sumber daya alam maupun sumber modal, dan lain sebagainya. Keterkaitan kemiskinan dengan pendidikan sangat besar karena pendidikan memberikan kemampuan untuk berkembang lewat penguasaan ilmu dan keterampilan. Pendidikan juga menanamkan kesadaran akan pentingnya martabat manusia.

Kunci untuk mendapatkan generasi cerdas dan produktif yaitu memotivasi masyarakat untuk belajar 12 tahun sesuai dengan aturan dari pemerintah, menyediakan pendidikan berkualitas bagi seluruh warga negara tanpa memandang apapun, status sosial ekonomi, etnisitas, suku bangsa, agama maupun bahasa. Setiap anak bangsa wajib mendapatkan pendidikan berkualitas sebagaimana diamanatkan dalam pembukaan UUD 1945 yang menyatakan salah satu tujuan negara mencerdaskan kehidupan bangsa.

Sebagai wilayah Ibu Kota Negara dan pusat pemerintahan, Provinsi DKI Jakarta berusaha semaksimal mungkin memberikan kemudahan dalam mengakses segala kebutuhan pendidikan sehingga masyarakat DKI Jakarta tidak mengalami kesulitan dalam mencapai Wajib Belajar 12 tahun. Pemerintah DKI Jakarta sendiri melalui Dinas Pendidikan Provinsi DKI Jakarta kemudian melaksanakan rintisan Wajib Belajar 12 tahun di tahun 2007.

Berdasarkan bantuan yang diberikan oleh pemerintah untuk warga DKI Jakarta, KJP bertujuan untuk: (i) mendukung terselenggaranya Wajib Belajar 12 Tahun, (ii) meningkatkan akses layanan pendidikan secara adil dan merata, dan (iii) menjamin kepastian mendapat layanan pendidikan dan meningkatkan kualitas hasil pendidikan. Dalam program Kartu Jakarta Pintar (KJP) Siswa yang berhak menerimanya harus memenuhi persyartan yang ada yaitu: (a) Warga DKI Jakarta yang dibuktikan dengan Kartu Keluarga (KK) atau surat keterangan lain yang dapat dipertanggungjawabkan, (b) Membuat surat pernyataan tidak mampu/miskin yang diketahui orang tua dan Ketua Rukun Tetangga (RT) setempat, (c) Terdaftar dan masih aktif di salah satu satuan pendidikan di Provinsi DKI Jakarta, (d) Diusulkan oleh sekolah yang telah ditandatangani oleh Kepala Sekolah, Kepala Satuan Pelaksana Pendidikan Kecamatan setempat yang selanjutnya diajukan ke Suku Dinas/Dinas Pendidikan setempat, (e) Menandatangani lembar Fakta Integritas yang telah disediakan. 
Siswa-siswi penerima beasiswa Kartu Jakarta Pintar (KJP) yaitu siswa miskin/ tidak mampu, siswa miskin/ tidak mampu itu adalah peserta didik pada jenjang satuan pendidikan sekolah dasar sampai dengan menengah yang secara personal dinyatakan tidak mampu baik secara materi maupun penghasilan orang tuanya yang tidak memadai untuk memenuhi kebutuhan dasar pendidikannya tersebut. Kebutuhan dasar pendidikan yang dimaksud mencakup di dalamnya yaitu seragam, sepatu, dan tas sekolah, biaya transportasi, makanan serta biaya ekstrakurikuler sekalipun.

Motivasi merupakan sesuatu proses mendorong siswa ke arah yang akan dilalui seorang siswa dalam belajar. Motivasi dapat berfungsi sebagai pendorong usaha dan pencapaian prestasi. Seseorang melakukan suatu usaha karena adanya motivasi. Motivasi bisa berasal dari internal siswa dan juga eksternal siswa, keduanya sangat mempengaruhi motivasi belajar yang dimiliki siswa yang menerima Kartu Jakarta Pintar (KJP). Para siswa-siswi yang menerima beasiswa program Kartu Jakarta Pintar (KJP) memiliki motivasi belajar yang berbeda-beda, ada yang memiliki motivasi belajar tinggi dan ada juga yang kurang memiliki motivasi dalam belajar.

Adanya motivasi yang baik dalam belajar akan menunjukkan hasil yang baik. Dengan kata lain, dengan adanya usaha yang tekun dan terutama didasari adanya motivasi, maka seseorang yang belajar itu akan dapat melahirkan prestasi yang baik. Intensitas motivasi seorang siswa akan sangat menentukan tingkat pencapaian prestasi belajarrnya. Dari pernyataan tersebut maka dapat dilihat jika motivasi dalam belajar menjadi faktor dominan dalam mencapai suatu keberhasilan belajar. Motivasi belajar siswa akan menjadi salah satu faktor pencapaian siswa dalam berprestasi di sekolah.

Konsep diri ini berkaitan dengan pandangan siswa yang menerima beasiswa Kartu Jakarta Pintar (KJP), seringkali konsep diri siswa memiliki arti negatif ketika mereka tidak percaya diri dengan kemampuan yang dimiliki karena mereka beranggapan bahwa mereka berasal dari keluarga kurang mampu. Tetapi jika siswa tersebut memiliki penialian yang positif tentang konsep diri mereka maka motivasi belajar dan keinginan untuk berprestasi itu tinggi. Motivasi belajar yang tinggi sehingga mereka dapat mencapai prestasi belajar yang baik maka konsep diri yang dihasilkan pun akan positif.

Berdasarkan pemikiran tersebut, penulis merasa tertarik untuk menelaah hal tersebut dalam penelitian dengan judul: Pengaruh Program Kartu Jakarta Pintar (KJP) Terhadap Motivasi Belajar Siswa di SMK Dharma Putra 1 Jakarta.

\section{LITERATURE REVIEW}

\section{Motivasi Belajar}

\section{a. Pengertian Motivasi Belajar}

Menurut Uno (2008:3) istilah motivasi berasal dari kata motif yang dapat diartikan sebagai kekuatan yang dapat dalam diri indibidu dan akan menyebabkan individu tersebut bertindak atau berbuat. Sardiman (2003:73) mengemukakan bahwa kata motif diartikan sebagai upaya yang mendorong seseorang untuk melakukan sesuatu motif juga dapat diartikan sebagai daya pengerak dari dalam dan didalamnya adalah subjek untuk melakukan aktivitasaktivitas tertentu demi mencapai tujuan.

\section{b. Bentuk-bentuk Motivasi Belajar Siswa}

Motivasi tumbuh dan berkembang dalam diri seseorang secara umun dengan jalan sebagai berikut:

1) Motivasi yang dating dalam diri individu sendiri 
2) Motivasi yang dating dari lingkungan sekitarnya.

Berdasarkan sumber dan proses perkembangannya, maka motivasi menurut Abin (2001:75) dapat digolongkan menjadi :

1) Motivasi Primer (Primery Motivation)

2) Motivasi Sekunder (Secondary Motivation)

\section{c. Ciri-ciri motivasi}

Menurut Sardiman AM (2003:83) motivasi memiliki ciri-ciri yaitu sebagai berikut:

1) Tekun menghadapi tugas (dapat bekerja terus menerus dalam waktu yang lama, tidak pernah berhenti sebelum selesai)

2) Ulet menghadapi kesulitan (tidak lekas putus asa)

3) Mewujudkan minat terhadap bermacam-macam masalah untuk orang dewasa.

4) Lebih senang bekerja sendiri

5) Cepat bosan pada tugas-tugas yang rutin

6) Dapat mempertahankan pendapatnya

7) Tidak mudah melepaskan hal yang diyakini itu

8) Senang mencari dan memecahkan masalah soal-soal

\section{d. Unsur-unsur Motivasi}

Menurut Dimyanti dan Mudjiono (1994:89-92) ada beberapa faktor yang mempengaruhi motivasi, yaitu:

1) Cita-cita atau aspirasi siswa

Cita-cita dapat berlangsung dalam waktu sangat lama, bahkan sepanjang hayat.

2) Kemajuan belajar

Dalam belajar dibutuhkan berbagai kemampuan. Kemampuan ini meliputi beberapa aspek psikis yang terdapat dalam diri siswa.

3) Kondisi jasmani dan rohani

Siswa adalah makhluk yang terdiri dari kesatuan psikofisik. Jadi kondisi siswa yang mempengaruhi motivasi belajar disini berkaitan dengan kondisi fisik dan kondisi psikologis, tetapi biasanya guru lebih cepat melihat kondisi fisik, karena lebih jelas menunjukkan gejalanya dari pada kondisi psikologis. Misalnya siswa yang kelihatan lesu, mengantuk mungkin juga karena malam harinya bergadang atau juga sakit.

4) Kondisi lingkungan kelas

Kondisi lingkungan merupakan unsur-unsur yang datangnya dari luar diri siswa.

5) Unsur-unsur dinamis belajar

Unsur-unsur dinamis dalam belajar adalah unsur-unsur yang keberadaannya dalam proses belajar yang tidak stabil, kadang lemah dan bahkan hilang sama sekali.

6) Upaya guru membelajarkan siswa

Upaya yang dimaksud disini adalah bagaimana guru mempersiapkan diri dalam membelajarkan siswa mulai dari penguasaan materi, cara menyampaikannya, menarik perhatian siswa. 


\section{e. Fungsi Motivasi Dalam Belajar}

Menurut Sardiman (2003:83) fungsi motivasi belajar tebagi tiga yakni:

1. Mendorong manusia untuk berbuat

Sebagai penggerak atau motor yang melepaskan energi. Motivasi dalam hal ini merupakan motor penggerak dari setiap kegiatan yang akan dikerjakan.

2. Menentukan arah perbedaan

Yakni ke arah tujuan yang hendak dicapai. Dengan demikian motivasi dapat memberikan arah dan kegiatan yang harus dikerjakan sesuai dengan rumusan tujuannya.

3. Menyeleksi perbuatan

Yakni menentukan perbuatan-perbuatan apa yang harus dikerjakan yang serasi guna mencapai tujuan, dengan menyisihkan perbuatan yang tidak bermanfaat dengan tujuan tersebut.

Sedangkan menurut Hamalik (2003:161) juga mengemukakan tiga fungsi motivas, yaitu:

1. Mendorong timbulnya kelakuan atau sesuatu perbuatan

2. Motivasi berfungsi sebagai pengarah

3. Motivasi berfungsi sebagai penggerak.

\section{f. Indikator Motivasi Belajar}

Menurut Uno (2011:23) menyebutkan indikator motivasi belajar yang berbeda, dapat diklasifikasikan sebagai berikut:

1) Adanya hasrat dan keinginan berhasil

2) Adanya dorongan dan kebutuhan dalam belajar

3) Adanya harapan atau cita-cita masa depan

4) Adanya penghargaan dalam belajar

5) Adanya kegiatan yang menarik dalam belajar

6) Adanya lingkungan belajar yang kondusif, sehingga memungkinkan seorang siswa dapat belajar dengan baik.

\section{g. Prinsip Motivasi Belajar}

Menurt Djamarah (2011) Terdapat beberapa prinsip motivasi dalam belajar seperti uraian berikut:

1. Motivasi sebagai dasar penggerak yang mendororong aktivitas belajar

Seseorang melakukan aktivitas belajar karena motivasi belum menunjukkan aktivitas yang nyata ada yang mendorongnya. Motivasilah sebagai dasar penggeraknya yang mendorong seseorang untuk belajar. Seseorang yang berminat untuk belajar belum sampai pada tataran motivasi belum menunjukkan aktivitas yang nyata. Minat merupakan kecendrungan psikologis yang menyenangi sesuatu objek, belum sampai melakukan kegiatan. Namun, minat adalah alat motivasi dalam belajar. Minat merupakan potensi psikologi yang dapat dimanfaatkan untuk menggali motivasi.

2. Motivasi instrinsik lebih utama daripada motivasi ekstrinsik dalam belajar 
Efek yang tidak diharapakan dari pemberian motivasi ekstrinsik adalah kecenderungan ketergantungan anak didik terhadap segala sesuatu di luar dirinya. Selain kurang percaya diri, anak didik juga bermental pengharapan dan mudah terpengaruh. Oleh karena itu, motivasi instrinsik lebih utama dalam belajar.

3. Motivasi berupa pujian lebih baik daripada hukuman

Setiap orang senang dihargai dan tidak disuka dihukum dalam bentuk apapun. Memuji orang lain berarti memberikan pengahargaan atas prestasi kerja orang lain. Hal ini memberikan semangat kepada seseorang untuk lebih meningkatkan prestasi kerjanya. Tetapi pujian yang diucap itu tidak asal ucap, harus pada tempat dan kondisi yang tepat. Kesalahan pujian bisa bermakna mengejek.

4. Motivasi berhubungan erat dengan kebutuhan dalam belajar

Dalam dunia pendidikan, anak didik membutuhkan penghargaan. Dia tidak ingin dikucilkan. Berbagai peranan dalam kehidupan yang dipercayakan kepadanya sama halnya memberikan rasa percaya diri kepada anak didik. Anak didik merasa berguna, dikagumi atau dohormati oleh guru atau orang lain. Perhatian, ketenaran, status, martabat, dan sebagainya merupakan kebutuhan yang wajar bagi anak didik, semuanya dapat memberikan motivasi bagi anak didik dalam belajar.

5. Motivasi dapat memupuk optimis dalam belajar

Anak didik yang mempunyai motivasi dalam belajar selalu yakin dapat menyelesaikan setiap pekerjaan yang dilakukan. Dia yakin belajar bukanlah kegiatan yang sia-sia. Hasilnya pasti akan berguna tidak hanya kini, tetapi juga di hari-hari mendatang.

6. Motivasi melahirkan prestasi dalam belajar

Dari berbagai hasil penelitian selalu menyimpulkan bahwa motivasi mempengaruhi prestasi belajar. Tinggi rendahnya motivasi selalu dijadikan indikator baik buruknya prestasi belajar seseorang anak didik.

\section{h. Upaya Meningkatkan Motivasi Belajar}

Menurut Djamarah (2002) Adapun upaya untuk meningkatkan motivasi belajar yaitu:

1. Menggairahkan anak didik

Upaya dapat meningkatkan kegairahan anak didik, guru harus mempunyai pengetahuan yang sukup mengenai disposisi awal keguiatan anak didiknya.

2. Memberikan harapan realistis Seorang guru harus memelihara harapan-harapan realistis dan memodifikasi harapan-harapan yang kurang atau tidak realistis.

3. Memberikan insentif

Bila anak didik mengalami keberhasilan, guru diharapkan memberikan hadiah kepada anak didik (dapat berupa pujian, angka yang baik, dan sebagainya) atas keberhasilannya, sehingga anak didik terdorong untuk melakukan usaha lebih lanjut guna mencapai tujuan-tujuan pengajaran.

4. Mengarahkan prilaku anak didik 
Cara mengarahkan perilaku anak didik adalah dengan memberikan penugasan, bergerak mendekati, meberikan hukuman yang mendidik, menegur dengan sikap lemah lembut dan dengan perkataan yang ramah dan baik.

\section{Kartu Jakarta Pintar (KJP)}

\section{a. Pengertian Kartu Jakarta Pintar (KJP)}

Kartu Jakarta Pintar adalah program strategis untuk memberikan akses bagi warga DKI Jakarta dari kalangan masyarakat tidak mampu untuk mengenyam pendidikan minimal sampai dengan tamat SMA/SMK dengan dibiayai penuh dari dana APBD Provinsi DKI Jakarta.Pemerintah DKI Jakarta sendiri melalui Dinas Pendidikan Provinsi DKI Jakarta kemudian melaksanakan rintisan Wajib Belajar 12 tahun di tahun 2007. Upaya tersebut terus berlanjut sehingga direncanakannya Wajib Belajar 12 tahun DKI Jakarta pada tahun 2012. Sebagai Ibu Kota negara tentunya menjadikan DKI Jakarta menjadi tujuan utama bagi arus urbanisasi seperti apa yang telah disampaikan sebelumnya. Tentunya dengan semakin meningkatnya angka urbanisasi disetiap tahunnya menjadikan karakteristik masyarakat DKI Jakarta menjadi sangat heterogen. Dengan latarbelakang seperti itu tentunya persoalan-persoalan terkait dengan pendidikan menjadi lebih beragam.Perlindungan sosial yang diberikan Pemerintah Provinsi DKI Jakarta kepada masyarakat miskin dalam bidang pendidikan, melalui program Kartu Jakarta Pintar (KJP). Program ini ditujukan bagi masyarakat miskin di DKI Jakarta sehingga anggota keluarga mereka dapat mengenyam pendidikan Wajib Belajar 12 Tahun.

\section{b. Tujuan Program Kartu Jakarta Pintar (KJP)}

Tujuan dari program Kartu Jakarta Pintar (KJP) pada dasarnya untuk memenuhi salah satu kebutuhan dasar yaitu dalam bidang pendidikan. Serta memberikan pelayanan sosial kepada masyrakat miskin agar anggota keluarga nya dapat menempuh pendidikan sampai jenjang SMA/SMK/Sederajat. Tujuan program Kartu Jakarta Pintar (KJP) sesuai dengan Peraturan Gubernur Provinsi DKI Jakarta No. 174 Tahun 2015 pasal 3 sebagai berikut:

1) Mendukung terselenggaranya wajib belajar 12 (dua belas) tahun;

2) Meningkatkan akses layanan pendidikan secara adil dan merata;

3) Menjamin kepastian mendapatkan layanan pendidikan; dan

4) Meningkatkan kualitas hasil pendidikan

\section{c. Manfaat dan Dampak Kartu Jarkarta Pintar (KJP)}

Manfaat dan dampak positif dari terselenggaranya Kartu Jakarta Pintar (KJP) antara lain:

1. Meningkatkan akses bagi anak usia 6 sampai dengan 21 tahun untuk mendapatkan layanan pendidikan sampai tamat satuan pendidikan menengah untuk mendukung pelaksanaan Pendidikan Menengah Universal/Rintisan Wajib Belajar 12 Tahun.

2. Meringankan biaya personal pendidikan.

3. Mencegah peserta didik dari kemungkinan putus sekolah (drop out) atau tidak melanjutkan pendidikan akibat kesulitan ekonomi. 
4. Mendorong siswa putus sekolah (drop out) atau anak tidak sekolah agar mendapatkan layanan pendidikan di sekolah/Sanggar Kegiatan Belajar (SKB)/Pusat Kegiatan Belajar Masyarakat (PKBM)/Lembaga Kursus dan Pelatihan (LKP) atau satuan pendidikan nonformal lainnya.

5. Meningkatkan pencapaian target Angka Partisipasi Kasar Pendidikan Dasar dan Menengah

6. Meningkatkan kesiapan siswa pendidikan menengah maupun peserta pendidikan kesetaraan dan kursus untuk memasuki pasar kerja atau melanjutkan ke jenjang pendidikan tinggi.

\section{d. Persyaratan Penerima Kartu Jakarta Pintar (KJP)}

Persyaratan penerima bantuan prorgram Kartu Jakarta Pintar (KJP) perlu untuk memenuhi persyarakat yang telah ditetapkan sebagai berikut:

1. Warga DKI Jakarta yang dibuktikan dengan Kartu Keluarga atau surat keterangan lain yang dapat dipertanggung jawabkan.

2. Membuat surat pernyataan tidak mampu/miskin yang diketahui orang tua dan Ketua Rukun Tetangga (RT) setempat.

3. Terdaftar dan masih aktif disalah satu satuan pendidikan di Provinsi DKI Jakarta.

4. Diusulkan oleh sekolah yang telah ditandatangani oleh Kepala Sekolah, Komite Sekolah, dan Kepala Dikdas/Dikmen Kecamatan setempat yang selanjutnya ke Suku Dinas/Dinas setempat. Menandatangani lembar Pakta Integritas yang telah disediakan

\section{e. Kriteria dalam Penerimaan Krtu Jakarta Pintar (KJP)}

Berdasarkan pengertian tersebut, maka untuk kepentingan pemenuhan kriteria program pemberian BPSM bagi SD/SMP/SMA/SMK//MA melalui Kartu Jakarta Pintar sebagai berikut :

1. Tidak merokok dan atau mengkonsumsi narkoba

2. Orang tua tidak memiliki penghasilan yang memadai

3. Menggunakan angkutan umum

4. Daya beli untuk sepatu dan pakaian seragam sekolah/pribadi rendah

5. Daya beli untuk buku, tas, dan alat tulis rendah

6. Daya beli untuk konsumsi makan/jajan rendah

7. Daya pemanfaatan internet rendah

8. Tidak dapat mengikuti kegiatan ekstrakurikuler yang berpotensi mengeluarkan biaya.

\section{METHODS}

Dalam penelitian ini, objek penelitian adalah SMK Dharma Putra 1 yang beralamat di Jl. Swasembada Barat XI no. 92, Kb Bawang, Tj. Priok Karta Utara, yang dilakukan pada bulan April 2019. Jenis penelitian yang dilakukan adalah kuantitatif dengan metode survey. Populasi dari objek yang diteliti adalah keseluruhan siswa kelas XII di SMK Dharma Putra 1 yang berjumlah 109 peserta didik yang terdiri dari 3 kelas yaitu: XII AP1, XII AP1, dan XII AP3, dengan sampel keseluruhan populasi yaitu sebesar 86 yang menggunakan teknik total sampling. Sementara teknik pengumpulan data yang dilakukan adalah melalui observasi, wawancara dan kuesioner. Variabel independen yang diteliti adalah variabel X (Kartu Jakarta Pintar) dan variabel dependen Y (Motivasi). Teknik 
analisa data yang dilakukan adalah Uji Validitas dan Reliabilitas data dengan menggunakan rumus korelasi Pearson Product Moment dan Alpha Cronbach. Selain itu peneliti juga menggunakan rumus Regresi Linier sederhana, Koefisien Korelasi Product Moment, serta Koefisien Determinan.

Hipotesis dalam penelitian ini adalah diduga ada pengaruh yang positif antara kartu Jakarta pintar (KJP) terhadap motivasi belajar siswa kelas XII di SMK Dharma Putra 1. Untuk membuktikan hipotesis yang dilakukan dalam penelitian ini.

\section{RESULTS \& DISCUSSION}

\section{Pengolahan Data Hasil Penelitian}

Pengumpulan data dalam penelitian ini yaitu menggunakan kuesioner yang berisikan 28 pernyataan dengan menggunakan pilihan jawaban menggunakan pilihan jawaban alternatif yang diajukan kepada 86 responden. Data-data yang diperlukan dalam penelitian ini diperolehh melalui instrument kuesioner yang berisikan 28 pernyataan dengan pilihan jawaban menggunakan alternatif jawaban. Data yang diperole dari penyebaran kuesioner ini merupakan data primer penelitian yang dilakukan. Pada bagian ini penelitian mendeskripsikan data hasil kuesioner 86 siswa. untuk memudahkan analisi data maka penelitian menyajikan dalam bentuk skor antar variabel.

Tabel 1.

Deskripsi Statistik Motivasi Belajar

\begin{tabular}{lr}
\hline N Valid & 86 \\
\multicolumn{1}{c}{ Missing } & 0 \\
\hline Mean & 62,97 \\
Std. Error of &, 746 \\
Mean & \\
Median & 63,00 \\
Mode & $65^{\mathrm{a}}$ \\
Std. Deviation & 6,919 \\
Variance & 47,869 \\
Range & 29 \\
Minimum & 49 \\
Maximum & 78 \\
Sum & 5415 \\
\hline Sum
\end{tabular}

Sumber :

Berdsarkan tabel diatas maka diketahui skor motivasi belajar siswa 86 responden siswa kelas XII di SMK Dharma Putra 1, diperoleh skor empirik terendah 49 dan skor empirik tertinggi 78. rentang skor 29, Rata-rata skor (mean) sebesar 62,97 simpangan baku 6,919, modus 65,00, median 63.

Tabel 2.

Deskripsi Statistik KJP

\begin{tabular}{lrr}
\hline $\mathrm{N}$ & Valid & 86 \\
& Missing & 0 \\
\hline Mean & 72,50 \\
Std. Error of Mean &, 846 \\
Median & 73,00 \\
\hline
\end{tabular}




\begin{tabular}{lr}
\hline Mode & $75^{\mathrm{a}}$ \\
Std. Deviation & 7,842 \\
Variance & 61,500 \\
Range & 39 \\
Minimum & 49 \\
Maximum & 88 \\
Sum & 6235 \\
\hline
\end{tabular}

Berdasarkan tabel diatas diketahui skor kartu jakarta pintar (KJP) 86 responden siswa kelas XII di SMK Dharma Putra 1, diperoleh skor empirik terendah 49 dan skor empirik tertinggi 88. rentang skor 39, jumlah kelas 6 dengan interval 6. Rata-rata skor (mean) sebesar 72,50 simpangan baku 7,842, modus 75, median 73,00.

\section{Analisi Data}

\section{Regresi Linier Sederhana}

Berdasarkan hasil perhitngan dengan menggunakan rumus statistik Regresi Linier Sederhana, maka diperoleh regresi sebesar $\mathrm{Y}=1,144+0,853 \mathrm{X}$

\section{Koefisien Korelasi}

Berdasarkan hasil perhitungan dengan menggunakan rumus statistik Koefisien Korelasi, maka pertama koefisien korelasi $\left(\mathrm{r}_{\mathrm{xy}}\right)=0,967$ dan $\mathrm{F}$ hit $(\mathrm{F}$ change $)=$ 1191,440, dengan p-value $=0,000<0,05$. Hal ini berarti Ho ditolak. Dengan demikian, koefisien korelasi $\mathrm{X}$ dan $\mathrm{Y}$ adalah berarti atau signifikan.

\section{Koefisien Determinasi}

Berdasarkan hasil perhitungan dengan menggunakan rumus statistik Koefisien Determinasi, yaitu R Square = 0,934 yang mengandung makna bahwa 93,4 \% variasi variabel motivasi belajar dapat dipengaruhi oleh kartu Jakarta Pintar (KJP).

\section{Uji Hipotesis}

Pengujian ini dimaksudkan untuk mengetahui apakah variabel X (Kartu Jakarta Pintar) dan variabel Y (Motivasi Belajar) berhubungan satu sama lain. Kemudian hasil dari thitung dibandingkan dengan $t_{\text {tabel }}$ dengan hasil sebagai berikut:

Dari hasil analisis $t_{\text {hitung }} 34,517$ dan p-value $0.00 / 2<0,05$ atau Ho ditolak. Dengan demikian "Kartu Jakarta Pintar (KJP) berpengaruh positif terhadap Motivasi Belajar".

\section{CONCLUSION}

Berdasarkan hasil penelitian yang dilakukan pada SMK Dharma Putra 1 mengenai "Pengaruh Kartu Jakarta Pintar (KJP) Terhadap Motivasi Belajar Kelas XII di SMK Dharma Putra 1", maka peneliti penelitian ini dapat disimpulkan sebagai berikut:

1. Hasil penelitian diketahui bahwa Motivasi Belajar Siswa dipengaruhi oleh Katu Jakarta Pintar (KJP), Hal ini dapat dilihat dari perhitungan anava sederhana didapat nilai p-value lebih kecil dari 0,05 dengan demikian Ho ditolak, regresi $\mathrm{Y}$ atau $\mathrm{X}$ adalah signifikan atau Kartu Jakarta Pintar berpengaruh terhadap Motivasi Belajar Siswa, dengan persamaan $\mathrm{Y}=1,144+0,853 \mathrm{X}$., demikian hipotesis penelitian didukung oleh data empiris.

2. Berdasarkan hasil uji koefisien korelasi, maka pertama koefisien korelasi $(\mathrm{r} x y)=$ 0,967 dan $\mathrm{F}$ hit $(\mathrm{F}$ change $)=1191,440$, dengan $\mathrm{p}$-value $=0,000<0,05$. Hal ini berarti Ho ditolak. Dengan demikian, koefisien korelasi $\mathrm{X}$ dan $\mathrm{Y}$ adalah berarti atau signifikan, sedangkan uji koefisien determinasi, yaitu $\mathrm{R}$ Square $=0,934$ yang 
mengandung makna bahwa 93,4 \% variasi variabel motivasi belajar dapat dipengaruhi oleh kartu Jakarta Pintar (KJP).

3. Dari hasil analisis $t_{\text {hitung }} 34,517$ dan p-value $0.00 / 2<0,05$ atau Ho ditolak. Dengan demikian "Kartu Jakarta Pintar (KJP) berpengaruh positif terhadap Motivasi Belajar".

\section{REFERENCES}

Abin, Syamsudin. (2001). Psikologi Kependidikan. Jakarta: Remaja Rosda Karya.

Dimyati dan Mudjiono. (1994). Balajar dan Pembelajaran. Jakarta: Depdikbud.

Djamarah, Syaiful Basri. (2002). Psikologi Belajar. Jakarta: PT. Rieneka Cipta.

Hadi, Sutrisno. (1998). Metodologi Research. Yogyakarta: Yayasan Penerbitan Fakultas Psikologi UGM.

Hamalik, Oemar. (2003). Prosedur Belajar Mengajar. Jakarta: Bumi Aksara.

Pemerintahan Indonesia. (2003). Undang-Undang No. 20 Tahun 2003 tentang Sistem Pendidikan Nasional. Undang-Undang Republik Indonesia. Sekretariat Negara.

Pemerintahan Indonesia. (2018). Peraturan Gubernur KJP No. 4 Tahun 2018 tentang Kartu Jakarta Pintar. Sekretariat Negara.

Sardiman, A.M. (2003). Interaksi dan Motivasi Belajar Mengajar. Jakarta Grafindo Persada.

Soemanto, Wasty. (2003). Psikologi Pendidikan. Malang: Rineka Cipta.

Uno, Hamzah B. (2008). Teori Motivasi dan Pengukurannya. Jakarta : Bumi Aksara.

Uno, Hamzah B. (2011). Teori Motivasi dan Pengukurannya. Jakarta: PT Bumi Aksara. 